\title{
THE FREQUENCY OF SYMPTOMS OF THE PREMENSTRUAL SYNDROME BY ADOLESCENT FEMALES WITH HEARING IMPAIRMENT
}

\author{
Elvira Čekić1 \\ Meliha Povlakić-Hadžiefendić \\ Center for hearing and speaking rehabilitation Sarajevo
}

Received: 08.11.2011

Accepted: 08.12.2011
Original scientific pape

UDC: $618.175-056.263$

$612.662-055.25$

\begin{abstract}
The aim of this study was to determine among adolescent females with hearing impairment the frequency of symptoms of the premenstrual syndrome. The tested sample consisted of 62 adolescents with hearing impairment, and the control sample 62 "hearing" adolescents, the average age of 14-16 years in Sarajevo and Tuzla. Measuring instruments that were used Diagnostic and Statistical Manual of Mental Disorders (DSM IV). The most dominant symptoms of PMS established in this research are: emotional instability, anger and irritability, sensitivity in breast area, headache and depressed mood. The following frequency of symptoms was found: apparent emotional instability (100\%), permanent and visible anger or irritability (90.32\%), apparent anxiety, feeling of tension (77.41), reduced interest in usual activities (70.96\%). There is no qualitative difference in the symptoms between adolescents with and without hearing impairment. There is a statistically significant difference in the prevalence of symptoms of the premenstrual syndrome in adolescents with hearing impairments compared to the control group adolescents.
\end{abstract}

Key words: menstrual cycle, premenstrual syndrome, symptoms of PMS, the auditory handicapped adolescents.

\section{INTRODUCTION}

The question of the menstrual cycle, premenstrual syndrome for the life of a woman and her functioning in the modern world has still been in the focus of the scientific circles, and we come across such questions in popular reading of the socalled "women's magazines", television, internet.

1 Correspodence to:

Elvira Čekić, Center for hearing and speaking rehabilitation Sarajevo

Ferhadija 13/III, Sarajevo, Bosnia and Herzegovina

Phone: +38761398002

E-mail: donelvira@gmail.com
Despite the general interest for the issues of menstrual cycle, which came into the focus during the "PMS hysteria" in 70ies, it seems as if we still do not have sufficient consistent information to identify the etiology of PMS, its manifestation to the rhythm of a woman's life, or its most effective treatment (Walker, 1997). 
Numerous questions arose which failed to provide consistent answers: What is it that we want to examine and diagnose, which is related to the menstrual cycle? Which are in fact the genuine symptoms of premenstrual syndrome? How are they spread and what is the intensity? Which symptoms are most characteristics for PMS? Affectionate and emotional or physiological and somatic? These questions become even more complex if we try to verify them on a specific target group, such as adolescent females with hearing impairment who have specific needs and go through characteristic phases of development, manifested through difficult communication, formation of identity, enhanced instincts for asocial patterns of behavior. We tried to provide answers through this research on these questions.

Phenomena like menstruation, pregnancy, birth delivery, and climax are only women related. The menstruation has been throughout the history the only evidence of female reproductive potential. As the result of such position, the scientists, doctors, and writers have focused on menstruation as a source of feminine feature and source of essential difference between men and women. Menstruation includes - periodic, cyclic, physiological bleeding from the uterus in time of female fertility, and is a characteristic of proper genital function of sexually mature woman (Sinanović, 2000). It is a physiological phenomenon and visible outer reflection of a cyclic function of ovary. The first menstruation is known as menarche. Menstruation starts in puberty and continues until menopause.

Although menstruation is not a rare or unusual event in our culture, as in many others, it is still considered as taboo. Thus, we know very little about the female experience of menstruation, who women felt in previous generations, and what is their feeling today. Contemporary understanding of PMS is reflected in an explanation that this is a series of physical, psychological, and emotional changes, which appear in the reproductive period of women, manifested in a way that they disturb the daily activities of women. More precisely, this is a chronic disorder of mood, which stops with the moment of menstruation bleeding, and its beginning starts in the last week of luteal phase (Balić, 2005, pp. 91-109).

Two specialized disciplines usually interested in the issues of PMS are gynecology and psychiatry. They both base their interest on whether the PMS is a "genuine" psychiatric or gynecological condition. Interest of gynecology and psychiatry into the same object of research resulted in a number of theories and "versatile" and confusing literature. One of the reasons for the confusion lies in the fact that experts from these disciplines do not speak always about the same concept, and their reasons and motives are also different. Gynecology is interested in every form of physical and emotional stress, as long as they are in any way related to menstruation cycle. Majority of gynecological researches adopted a broad definition of PMS, directed at seriousness of symptoms and their temporary connection with menstrual cycle (Bäckström \& Hammarbäck, 1991, pp. 625-633).

Psychiatry, on the other hand, studies in general terms and the potentialtreatments of conditions conceptualized as "psychiatric conditions" or "psychiatric illnesses", such as schizophrenia or depression. From the psychiatric viewpoint, the premenstrual symptoms, reported by the examinees, are not important, only the emotional experiences are important, especially depression, anxiety, tension, irritation, anger, mood change, or emotional instability, as we can see among the criteria of the Diagnostic Statistic Manual for mental conditions (Anonymous, 1998). 
Menstruation among the adolescents is a biological indicator of sexual maturity. Not much attention was devoted to this relevant period, which resulted in the fact that we have abundance of disharmonized data. This information is particularly relevant for girls with impairments in their development. Not a single research has been found so far related to this issue of adolescents with hearing impairment. In addition to the puberty, the adolescence has been an important part of a life cycle of a woman, and it is so important due to the obvious changes at the emotional, social, sexual, or personal level (Lacković-Grgin, 2006).

In addition to the usual changes, which make part of live of every adolescent, the adolescents with certain deficits and deficiencies, such as adolescents with hearing aberration, come across different visible problems, as most often, due to the lack of understanding of their peers, they are exposed to stigmatization, isolation, marginalization, harassment, or even violence (Radoman, 1994).

The deaf persons have been exposed to an additional stress in the course of communication and they have experienced frustration and humiliating communication experiences. As a response to such reaction by the environment, the persons with hearing impairment have developed a series a negative features such as: emotional instability, depression, shyness, egotism, inability to sympathize, neurotic reactions (Živković, 1996). This could be a special problem given that the phase of adolescence is a phase of developmental crisis, symbolized as formation of identity vis-àvis confusion of identity. Being unaccepted and rejected can result in the development of feeling of inferiority and a series of other disturbances, which may have a determining force in a subsequent life of a person.
Considering the complexity of life circumstances, in which the adolescents with hearing aberration live, the attempts were made to identify somatic and psychological symptoms of PMS, manifested throughout the menstrual cycle. Are the PMS symptoms different in the adolescents with hearing impairment in relation to the adolescents without any hearing problems, especially considering the expressed impulsiveness and sensitivity of those with hearing impairment? Do PMS symptoms differ only in quantity, that is, by the intensity, or are there any differences in terms of quality? Which are the most significant PMS symptoms in adolescents with hearing impairment?

\section{EXAMINEES AND WORK METHODS}

The population of the examined entity were adolescents with hearing aberration. The sample consisted of two sub-samples of 14-16 years in age. The first sub-sample were adolescents with hearing impairment from the Center for the hearing and speaking rehabilitation in Sarajevo and the adolescents from the Center for upbringing, education, training, and rehabilitation in Tuzla. The total number of examinees was 62, of which 12 were from the Tuzla Canton. The second sub-sample was made of examinees without any hearing problems, also 62 adolescents from the General High School Prva Bošnjačka Gimnazija and Secondary School for Applied Arts in Sarajevo.

The measurement instrument was Questionnaire on the symptoms of premenstrual syndrome. This Questionnaire was prepared based on the Diagnostic Manual for mental disorders for the premenstrual syndrome/premenstrual dysphoric disorder (Anonymous, 1998) and pertains to symptoms which symbolizes indicators and 
problems related to PMS. The Questionnaire is made of 11 symptoms, which the examinees have to range in accordance with frequency and intensity.

The date obtained in Questionnaires were processed in computers in line with the single variant and multi variant analytical procedures. Following programs were used for the analysis: PASW (Predictive Analytics Software) 18 and MS Excel 2007. As for the statistical procedures, the descriptive procedure was used, as well as $\mathrm{t}$ test, and the analysis of variance, Mann Whitney $U$ test, Kendall coefficient $\tau-b$, coefficient of concordation W, Hi square test. Spss macro rtt9g was used for the analysis of material features.

\section{RESULTS}

Symptoms of premenstrual syndrome are divided in three categories: somatic symptoms (gas on the stomach, acne, breast sensitivity, headache), psychological symptoms (crying, depression, forgetting, sensitivity, mood change from sorrow to the anger, inclination to arguments, avoidance of any company) and symptoms of appetite disorder (taking food more than usual, taking food less than usual, enhanced desire for certain foods).

Frequency of symptoms of premenstrual syndrome are shown in Table 1.
Table 1 shows indicators of frequency of each of the premenstrual syndrome symptoms in adolescents with disturbances. Analog with this, it was concluded that the most frequent symptoms of premenstrual syndrome in adolescents with hearing impairment are:

$>$ Emotional instability (sudden feeling of sorrow or tears or increased sensitivity to rejection) (100\%)

Permanent and visible rage or irritation or increased inclination to conflicts with people $(90.32 \%)$

$>$ Anxiety, feeling of tension (77.41\%)

$>$ Reduced interest in usual activities $(70.96 \%)$

The diagnosed symptoms were tested so as to identify if there is any significant statistical difference in occurrence of relevant PMS symptoms in a group with hearing impairment.

Table 2. Friedman and Kandall test of significance of concordance of ranks in adolescents

with hearing impairment

\begin{tabular}{lcccc}
\hline & $\mathrm{N}$ & Hi-square $\chi^{2}$ & Df & Significance \\
\hline Friedman Test & 14 & 110.59 & 10 & 0.01 \\
Kandall test & 14 & 110.59 & 10 & 0.01 \\
\hline
\end{tabular}

\section{Table 1. Frequency of symptoms of premenstrual} syndrome in adolescents with hearing impairment

\begin{tabular}{|c|c|c|}
\hline Symptoms: & $\mathrm{N}$ & Frequency \\
\hline Visible emotional instability (sudden feeling of sorrow or tears or increased sensitivity to rejection) & 62 & $100.00 \%$ \\
\hline Permanent and obvious rage or irritation or strong inclination to conflicts with people & 56 & $90.32 \%$ \\
\hline Depressive mood, feeling of helplessness or lack of self esteem & 29 & $48.38 \%$ \\
\hline Change in appetite, "overeating" or desire for certain foods & 30 & $48.38 \%$ \\
\hline Other physical symptoms such as breast sensitivity, headache, muscle or joint pain, feeling of & & \\
\hline "flatulence", gaining weight & 38 & $61.29 \%$ \\
\hline Anxiety, feeling of tension that everything is "tense" or at the edge & 36 & $58.06 \%$ \\
\hline Reduced interest in usual activities (i.e. work, school, friends, hobbies) & 48 & $77.41 \%$ \\
\hline Subjective feeling of being "overpowered" or lack of control & 44 & $70.96 \%$ \\
\hline Subjective feeling of lack of focus & 34 & $54.83 \%$ \\
\hline Lethargy, quick fatigue, visible lack of energy & 38 & $61.29 \%$ \\
\hline Hypersomnia or insomnia & 32 & $51.62 \%$ \\
\hline
\end{tabular}


As it may be seen, there is a significant statistical difference in preference, that is, manifestation of the PMS symptoms in adolescents with hearing impairment $(\mathrm{W}=0.79 ; \mathrm{p}<0.01)$, which means that the PMS symptoms such as emotional instability, rage, irritation, increased in inclination to conflicts with people, anxiety, and reduced interest in usual activities are far more frequent than the other symptoms.

The same procedure was applied to a control group of adolescents, so that the frequency of premenstrual syndrome symptoms could be tested as well.

Table 3. Frequency of symptoms of premenstrual syndrome in a control group of adolescents

\begin{tabular}{lll}
\hline Symptoms: & N & Frequency \\
Visible emotional instability (sudden feeling of sorrow or tears or increased sensitivity to rejection) & 62 & $100.00 \%$ \\
Permanent and obvious rage or irritation or strong inclination to conflicts with people & 58 & $93.54 \%$ \\
Depressive mood, feeling of helplessness or lack of self esteem & 27 \\
Change in appetite, "overeating" or desire for certain foods & $56.54 \%$ \\
Other physical symptoms such as breast sensitivity, headache, muscle or joint pain, feeling of & 31 \\
"flatulence", gaining weight & $40.32 \%$ \\
Anxiety, feeling of tension that everything is "tense" or at the edge & $50.00 \%$ \\
Reduced interest in usual activities (i.e. work, school, friends, hobbies) & 46 \\
Subjective feeling of being "overpowered" or lack of control & 20 \\
Subjective feeling of lack of focus & 38 \\
Lethargy, quick fatigue, visible lack of energy & $32.25 \%$ \\
Hypersomnia or insomnia & $36 \%$ \\
\hline
\end{tabular}

Table 3 shows indicators of frequency of each of the premenstrual syndrome symptoms in a control group of adolescents. It was concluded that the most frequent symptoms of premenstrual syndrome in the control group of adolescents are:

$>$ Emotional instability (sudden feeling of sorrow or tears or increased sensitivity to rejection) (100\%)

Permanent and visible rage or irritation or increased inclination to conflicts with people $(93.54 \%)$
Visible change in appetite, "overeating" or desire for certain foods $(90.32 \%)$

$>$ Reduced in interest for usual activities (74.19\%)

Then, it was concluded that the manifested PMS symptoms differ significantly in statistics by its occurrence in the control group of adolescents. This was also determined by the Kandall test of significance of ranks. The results of the analysis are given in the Table 4.

Table 4. Friedman and Kandall test of significance of concordance of ranks in a control group of adolescents

\begin{tabular}{lcccc}
\hline & N & Hi-square $\chi^{2}$ & Df & Significance \\
\hline Friedman Test & 15 & 73,62 & 10 & 0.01 \\
Kandall test & 15 & 73,62 & 10 & 0.01 \\
\hline
\end{tabular}

The Table 4 clearly shows the statistically significant difference in preferences, that is, the manifestation of PMS symptoms in the control group of adolescents $(\mathrm{W}=0.49 ; \mathrm{p}<0.01)$, which means that the PMS symptoms, separated in the analysis, are statistically more frequent in relation to the other symptoms.

Then, the testing of differences in the manifestation of PMS symptoms was done in the control and the group of adolescents with hearing impairment, 
so as to identify the symptoms characteristics

for the adolescents with hearing impairment.

During the process of verification of results, the

non-parametric procedure of Mann Whitney test

was used to examine the relevance of differences

between these two groups.

Table 5. Descriptive statistics for the symptoms of premenstrual syndrome in a group of adolescents with hearing impairment and a control group of adolescents

\begin{tabular}{|c|c|c|c|c|}
\hline & Sub-sample & $\mathrm{N}$ & $\begin{array}{l}\text { Average } \\
\text { rank }\end{array}$ & $\begin{array}{l}\text { Total of } \\
\text { ranks }\end{array}$ \\
\hline \multirow{2}{*}{$\begin{array}{l}\text { Visible depressive mood, } \\
\text { Feeling of helplessness or no self esteem }\end{array}$} & Control group & 27 & 33.28 & 898.50 \\
\hline & $\begin{array}{l}\text { Group with hearing } \\
\text { impairment }\end{array}$ & 30 & 25.15 & 754.50 \\
\hline \multirow{2}{*}{$\begin{array}{l}\text { Visible anxiety, feeling of tension } \\
\text { that it is "tense" or at the edge }\end{array}$} & Control group & 43 & $39.60 *$ & 1703.00 \\
\hline & $\begin{array}{l}\text { Group with hearing } \\
\text { impairment }\end{array}$ & 48 & 51.73 & 2483.00 \\
\hline \multirow{2}{*}{$\begin{array}{l}\text { Emotionally unstable (i.e. sudden feeling of sorrow, tears or } \\
\text { increased sensitivity to rejection). }\end{array}$} & Control group & 62 & 71.92 & 4459.00 \\
\hline & $\begin{array}{l}\text { Group with hearing } \\
\text { impairment }\end{array}$ & 62 & $53.08 *$ & 3291.00 \\
\hline \multirow{2}{*}{$\begin{array}{l}\text { Permanent and visible rage, irritation, increased conflicts with } \\
\text { People }\end{array}$} & Control group & 58 & 66.78 & 3873.00 \\
\hline & $\begin{array}{l}\text { Group with hearing } \\
\text { impairment }\end{array}$ & 56 & $47.89 *$ & 2682.00 \\
\hline \multirow{2}{*}{$\begin{array}{l}\text { Reduced interest in usual activities (i.e. work, school, friends, } \\
\text { hobbies) }\end{array}$} & Control group & 46 & 41.11 & 1891.00 \\
\hline & $\begin{array}{l}\text { Group with hearing } \\
\text { impairment }\end{array}$ & 44 & 50.09 & 2204.00 \\
\hline \multirow[b]{2}{*}{ Subjective feeling of lack of focus } & Control group & 38 & 37.61 & 1429.00 \\
\hline & $\begin{array}{l}\text { Group with hearing } \\
\text { impairment }\end{array}$ & 34 & 35.26 & 1199.00 \\
\hline \multirow[b]{2}{*}{ Lethargy, quick fatigue, or lack of energy } & Control group & 36 & 46.06 & 1658.00 \\
\hline & $\begin{array}{l}\text { Group with hearing } \\
\text { impairment }\end{array}$ & 38 & $29.39 *$ & 1117.00 \\
\hline \multirow{2}{*}{$\begin{array}{l}\text { Visible change in appetite, "overeating" or desire for specific } \\
\text { foods }\end{array}$} & Control group & 56 & $36.79 *$ & 2060.00 \\
\hline & $\begin{array}{l}\text { Group with hearing } \\
\text { impairment }\end{array}$ & 36 & 61.61 & 2218.00 \\
\hline \multirow[b]{2}{*}{ Hypersomnia or insomnia } & Control group & 34 & $29.09 *$ & 989.00 \\
\hline & $\begin{array}{l}\text { Group with hearing } \\
\text { impairment }\end{array}$ & 32 & 38.19 & 1222.00 \\
\hline \multirow[b]{2}{*}{ Subjective feeling of being "overpowered" or lack of control } & Control group & 20 & 16.53 & 330.50 \\
\hline & $\begin{array}{l}\text { Group with hearing } \\
\text { impairment }\end{array}$ & 15 & 19.97 & 299.50 \\
\hline \multirow{2}{*}{$\begin{array}{l}\text { Other physical symptoms such as sensitivity of breasts, } \\
\text { headache, muscle or joint pain, , feeling of gas on stomach, } \\
\text { gaining weight }\end{array}$} & Control group & 31 & 31.82 & 986.50 \\
\hline & $\begin{array}{l}\text { Group with hearing } \\
\text { impairment }\end{array}$ & 29 & 29.09 & 843.50 \\
\hline
\end{tabular}


Table 5 shows the average ranks and totals of significant difference between the groups, are ranks for the PMS symptoms in both groups of shown in red color, in a way that the group with examinees. Symptoms, marked with statistically more obvious symptom is marked.

Table 6. Indicators of difference on the scales of symptoms of premenstrual syndrome

\begin{tabular}{|c|c|c|c|c|c|c|c|c|c|c|c|}
\hline & $\begin{array}{c}\text { Visible } \\
\text { depre- } \\
\text { ssive } \\
\text { mood, } \\
\text { feeling } \\
\text { of } \\
\text { helple- } \\
\text { ssness } \\
\text { or no } \\
\text { self } \\
\text { esteem }\end{array}$ & $\begin{array}{l}\text { Visible } \\
\text { anxiety, } \\
\text { feeling } \\
\text { of } \\
\text { tension } \\
\text { that it is } \\
\text { "tense" } \\
\text { or at the } \\
\text { edge }\end{array}$ & $\begin{array}{c}\text { Emoti- } \\
\text { onally } \\
\text { unsta- } \\
\text { ble }\end{array}$ & $\begin{array}{l}\text { Visible } \\
\text { rage, } \\
\text { irritation, } \\
\text { increased } \\
\text { conflicts } \\
\text { with } \\
\text { people }\end{array}$ & $\begin{array}{c}\text { Reduced } \\
\text { interest } \\
\text { in usual } \\
\text { activities }\end{array}$ & $\begin{array}{l}\text { Lack } \\
\text { of } \\
\text { focus }\end{array}$ & $\begin{array}{l}\text { Letha- } \\
\text { rgyquick } \\
\text { fatigue, } \\
\text { lack of } \\
\text { energy }\end{array}$ & $\begin{array}{l}\text { Change in } \\
\text { appetite, } \\
\text { overea-ting } \\
\text { or desire } \\
\text { for specific } \\
\text { foods }\end{array}$ & $\begin{array}{l}\text { Hyper- } \\
\text { somnia or } \\
\text { insomnia }\end{array}$ & $\begin{array}{c}\text { Feeling } \\
\text { of } \\
\text { being } \\
\text { overpowered } \\
\text { or lack of } \\
\text { control }\end{array}$ & $\begin{array}{c}\text { Other } \\
\text { physical } \\
\text { symptoms }\end{array}$ \\
\hline $\begin{array}{c}\text { Mann- } \\
\text { Whitney U }\end{array}$ & 289.5 & 757 & 1338 & 1086 & 810 & 604 & 376 & 464 & 394 & 120.5 & 408 \\
\hline $\begin{array}{c}\text { Wilcoxon } \\
\text { W }\end{array}$ & 754.50 & 1703 & 3291 & 2682 & 1891 & 1199 & 1117 & 2060 & 989 & 330 & 843 \\
\hline $\mathrm{Z}$ & -1.89 & -2.21 & -3.051 & -3.10 & -1.64 & -0.48 & -3.37 & -4.39 & -2.69 & -1.00 & -0.61 \\
\hline Relevance & 0.06 & $0.02 *$ & $0.00^{*}$ & $0.00 *$ & 0.10 & 0.62 & $0.00^{*}$ & $0.00 *$ & $0.00^{*}$ & 0.31 & 0.53 \\
\hline
\end{tabular}

Table 6 shows the values of Mann Whitney test. Variables with statistically significant relevance are marked with red color.

Thus, based on the results, it is possible to conclude the following:

$>$ That the premenstrual syndrome "anxiety" is statistically far more present in the control group adolescents $(\mathrm{p}<0.05)$;

$>$ That the premenstrual syndrome "emotional instability" is statistically far more present in adolescents with hearing impairment $(\mathrm{p}<0.01)$;

$>$ That the "irritation or rage, human conflicts" are statistically far more present in adolescents with hearing impairment $(\mathrm{p}<0.01)$;

$>$ That the lethargy, quick fatigue, lack of energy are statistically far more manifested in adolescents with hearing impairment $(\mathrm{p}<0.01)$;
That the change in appetite, overeating are statistically far more present in the control group adolescents $(\mathrm{p}<0.01)$;

$>$ That the hypersomnia or insomnia are statistically far more manifested in the control group adolescents $(\mathrm{p}<0.01)$.

\section{DISCUSSION AND CONCLUSION}

The objective is research was to establish the frequency of symptoms of premenstrual syndrome in adolescents with hearing impairment. The results indicate that the following PMS symptoms are dominant in adolescents with hearing aberration: emotional instability usually manifested in the emotion of sorrow, tears, and increased sensitivity to rejection; obvious and manifesting irritation manifested through increased inclination to conflicts in interpersonal relations. In addition to these symptoms, the somatic symptoms are also present such as sensitivity of breasts, headache, 
muscle or joint pain; feeling of flatulence. As for the psychological symptoms, it is worth noting the presence of depressive mood, inclination to a low self esteem, perception that everything is so hopeless and desperate. These symptoms in adolescents with hearing impairment are statistically far more present than the other symptoms which occur during the premenstrual period.

As for the adolescents who have functional hearing apparatus, similar symptoms were found as in adolescents with hearing impairment. However, it is important to note that the manifested symptoms have stronger intensity in adolescents with hearing impairment. Unlike the adolescents with hearing impairment, the adolescents with functional hearing apparatus suggest stronger symptoms manifested in enhanced change in appetite, inclination to “overeating” or increased desire for certain foods. These symptoms are statistically far more frequent than the other symptoms which occur during the premenstrual cycle.

The frequency of the following symptoms in adolescents with hearing impairment were noted: visible emotional instability (100\%), permanent and visible rage or irritation $(90.32 \%)$, anxiety, feeling of tension (77.41), reduced interest in usual activities $(70.96 \%)$. The most frequent symptoms in the control group of adolescents were: visible emotional instability (100\%), permanent and visible rage or irritation (93.54\%), visible change in appetite, "overeating" or desire for certain foods $(90.32 \%)$, and reduced interest in usual activities (74.19\%).

As for the specific testing of which symptoms are statistically far more present among the examinees, the adolescents with hearing impairment suggest stronger presence of emotional instability, feeling of fatigue and lethargy, loss of energy. On the other hand, the adolescents with functional hearing apparatus suggested stronger presence of anxiety, change in appetite, tendency towards "overeating", and increased desire to taste different foods.

As for the specific differences in symptoms between these two groups of examined adolescents, it may be concluded that the difference is mainly quantitative. Thus, both groups of examinees suggested the presence of same symptoms, just different intensity. Perhaps, the only acceptable explanation as to why the adolescents with hearing impairment suffer from stronger emotional instability, feeling of fatigue, and loss of energy could be that these individuals are far more impulsive than the individuals with hearing aberration. Impulsiveness is a characteristic of persons to react instantaneously, quickly, without any prior planning or thinking. The reactions are based on a desire to satisfy their needs and demands. Numerous scholars have already pointed out this fact. In this way, their instability and fatigue are far more evident under the influence of premenstrual cycle. 


\section{REFERENCE}

Anonimus, (1998). Dijagnostički i statistički priručnik za duševne poremećaje s MKB-10 šiframa. Jastrebarsko, Croatia: Naklada Slap.

Balić, D. (2005). Ginekologija dječije i adolescentne dobi [Gynaecology of child and adolescent age]. In Fatušić et al. Ginekologija [Gynaecology]. (pp. 91-109). Tuzla, B\&H: PrintCom d.o.o. grafički injžering.

Bäckström, T., Hammarbäck, S. (1991). Premenstrual syndrome - psychiatric or gynaecological disorder? Ann Med. 23(6): 625-633.

Lacković-Grgin, K. (2006). Psihologija adolescencije [Psychology of adolescence]. Jastrebarsko, Croatia: Naklada Slap.

Radoman, V. (1984). Uloga čula sluha, gluhoće u razvoju odnosa adolescenata sa objektima [The role of the senses of hearing, deafness in developing relationships of adolescents with the objects], Psihologija, No.1.

Sinanović, O. (2000). Psihički poremećaji žena vezani za menstruaciju, trudnoću, porođaj i menopauzu [Psychological disorders in women associated with menstruation, pregnancy, childbirth and menopause]. In Loga S, Cerić I, Sinanović O. Psihički poremećaji žena [Psychological disorders in women]. Osmi psihijatrijski dani Bosne i Hercegovine. Udruženje psihijatara Bosne i Hercegovine Sarajevo 2: 1517. $\mathrm{B} \& \mathrm{H}$.

Walker, A. (1997). The Menstrual Cycle. London and New York: Routledge.

Živković, M. (1996). Psihologija gluve $i$ nagluve dece $i$ omladine [Psychology of hearing impaired children and adolescents]. Belgrade, Serbia: Zavod za uđžbenike i nastavna sredstva. 